\title{
COERÊNCIA PROGRAMÁTICA E DISCIPLINA PARLAMENTAR: PARTIDOS POLÍTICOS FRENTE À PROPOSTADAS ORGANIZAÇÕES SOCIAIS ${ }^{1}$
}

\author{
Vera Viviane Schmidt
}

\begin{abstract}
RESUMO
Este artigo trata sobre o efeito dos partidos politicos no processo decisório de uma política de reforma do Estado denominada organizações sociais. Analisa-se sua proposição e tramitação legislativa em nivel federal e estadual (no estado de São Paulo) e sua adoção pelos estados brasileiros no período compreendido entre 1995 e 2006. Referente à adoção da política pelos estados, estudos realizados neste trabalho considerando a situação das administrações estaduais, o partido político no governo e a adoção ou não da política - sugerem a filiação partidária do Governador como proxi de sua decisão em aderir ou não ao modelo via à vis argumentos de cunho econômico/fiscal. A análise legislativa demonstrou relevância dos partidos na estruturação do processo decisório e na orientação do voto disciplinado dos parlamentares. A posição de cada partido foi, para o caso observado, coerente com seus respectivos programas.
\end{abstract}

PALAVRAS-CHAVE: organizações sociais; partidos políticos; políticas públicas.

\section{INTRODUÇÃO}

O papel dos partidos políticos no direcionamento da ação dos componentes dos poderes Executivo e Legislativo tem recebido atenção, embora diluída, dos acadêmicos nas últimas décadas. Inspirados em modelos neoinstitucionalistas norte-americanos, estudos realizados sobre o Brasil revelam conclusões em sentidos divergentes. Por um lado, pesquisadores como Lima Jr. (1983), Lamounier (1992), Shugart e Carey (1992), Sartori (1993; 1994), Mainwaring e Shugart (1997) e Stepan (1999) atestam um país ingovernável dada a conformação de suas instituições políticas e à fragilidade de suas organizações partidárias. Segundo esses autores, os partidos políticos seriam, no Brasil, organizações pouco coesas e com dimensões programática e ideológica inconsistentes, o que,

\footnotetext{
1 Este artigo resultou de minha dissertação de Mestrado em Ciência Política (Universiadde de São Paulo (USP)), 2007). Uma versão preliminar foi apresentada no $6^{\circ}$ encontro da Associação Brasileira de Ciência Política (ABCP), realizado em Campinas, em agosto de 2008. Agradeço os comentários dos pareceristas anônimos da Revista de Sociologia e Politica.
}

associado à luta por interesses corporativos no acesso a representações parlamentares, inviabilizariam a formação de uma base parlamentar ao Presidente, comprometendo seriamente a capacidade decisória. Por outro lado, pesquisadores como Figueiredo e Limongi (1999) demonstraram que o arranjo institucional brasileiro existente a partir da Constituição de 1988 concentra o processo decisório nas mãos do Executivo, e que parâmetros partidários servem como eixos estruturadores da atividade legislativa e do comportamento parlamentar, o que permite a governabilidade.

Este artigo objetiva contribuir para o debate sobre a relevância dos partidos políticos no processo decisório no Brasil, por meio da análise do desenho, tramitação parlamentar e adoção pelos estados de uma política elaborada no cerne da reforma do aparelho de Estado no Brasil denominada "organizações sociais" (OS).

A proposta das OS foi formulada por Luiz Carlos Bresser-Pereira e sua equipe, quando Ministro da Administração Federal e Reforma do Estado (MARE), durante o primeiro mandato presidencial de Fernando Henrique Cardoso (FHC) (Partido da Social-Democracia Brasileira (PSDB), 
1995-1999). A proposta foi desenvolvida como um modelo para a provisão dos serviços públicos por meio de parcerias entre o Estado e organizações não-estatais. Tendo por base experiências realizadas em países como a Inglaterra da Era Thatcher e os Estados Unidos da Era Reagan, a proposta compôs um rol maior de medidas adotadas durante a segunda geração de reformas ${ }^{2}$, difundidas a partir da década de 1990 no Brasil. Inicialmente apresentada no Plano Diretor de Reforma do Aparelho de Estado (BRASIL. PRESIDÊNCIA DA REPÚBLICA, 1995), alcançou seu marco legal na Medida Provisória n. 1 591-1, de 6 de novembro de 1997 (BRASIL, 1997), reeditada até a conversão na Lei n. 9 637, de 15 de maio de 1998 (BRASIL, 1998b).

Como proposta de reforma que visava alterar o status quo do funcionalismo público e a forma de gestão de unidades prestadoras de serviços de áreas como saúde, cultura e educação, a Lei suscitou críticas e oposição dos partidos de esquerda, das organizações de classe, dos conselhos de saúde, da burocracia e mesmo de Ministros de áreas-chave de políticas sociais. Embora contrários ao modelo, esses atores não alcançaram vetar a aprovação da matéria proposta pelo poder Executivo em ambas as tramitações aqui observadas (Congresso Nacional e Assembléia Legislativa do Estado de São Paulo), tampouco conseguiram o veto do poder Judiciário. À iniciativa federal seguiram-se iniciativas estaduais, e mesmo municipais, no sentido de adotar o modelo OS.

Argumenta-se aqui pela relevância dos partidos políticos no processo decisório parlamentar, bem como a influência de parâmetros partidários para compreender a decisão dos governadores em aderir ou não ao modelo vis à vis argumentos de cunho econômico-fiscal presentes na literatura.

$\mathrm{O}$ artigo é organizado em três tópicos, além desta "Introdução" e das "Considerações finais": instituições, atores e preferências, que organiza os argumentos da literatura sobre o papel dos partidos políticos na decisão dos atores políticos

\footnotetext{
$2 \mathrm{O}$ movimento não possuía caráter tão eminentemente econômico, mas de reconstrução das capacidades estatais e reacomodação de prioridades a serem atendidas, visando a reformar o aparelho de Estado (COSTA, 1998; GAETANI \& HEREDIA, 2002; MELO, 2002).
}

e fornece a base teórico-metodológica para tratar dos dados empíricos apresentados e analisados na seqüência; posições políticas frente à proposta OS, em que é realizada a identificação dos atores e das posições programáticas dos partidos políticos frente à proposta; proposição e tramitação legislativa e adoção do modelo OS nos estados brasileiros em que são apresentados dados que permitem argumentação contrária à literatura que atesta serem os partidos políticos, no Brasil, organizações fracas, indisciplinadas e destituídas de dimensões programáticas nacionais.

\section{INSTITUIÇÕES, ATORES E PREFERÊN- CIAS}

Estudos que seguem a perspectiva neoinstitucionalista concentram suas explicações nas escolhas políticas estratégicas dos atores racionais, cujo comportamento irá depender dos interesses e objetivos destes e de como as regras do jogo estruturam a competição política (KAUFMAN, 1998, p. 51). Preocupam-se, esses estudos, em identificar quais instituições afetam o comportamento dos indivíduos e a forma como o fazem (HALL \& TAYLOR, 2003, p. 58).

As instituições atuam enquanto estruturas de mediação dos conflitos políticos do qual os atores são parte componente, são "regras, leis procedimentos, normas, arranjos institucionais e organizacionais [que] implicam a existência de constrangimentos e limites ao comportamento", que podem influenciar os resultados no processo político (LIMONGI, 1994, p. 1). Elas agem como delimitadoras do campo de decisão, determinando as arenas de veto em uma cadeia decisória e delimitando um possível poder de veto dos atores nessas arenas (IMMERGUT, 1996, p. 140). Tal perspectiva teórica auxilia a compreensão de decisões referentes à reforma do Estado como "intra-estatais" ao identificar que, mesmo existindo impulsos externos para as reformas (situação administrativa, econômica etc.) é a classe política que responde a esses incentivos.

À competição política envolta no processo, os partidos importam. O agente racionaliza suas chances pessoais de sobrevivência política com as metas assumidas pelo grupo partidário ao qual pertence, sendo que os papéis institucionais e a distribuição dos recursos políticos afetarão suas escolhas. Essa escolha dos legisladores refletirá, ainda, na forma como as instituições envoltas no 
processo e a conformação de seu partido afetam suas chances de reeleição. As possíveis soluções aos problemas da reforma são admitidas de acordo com certas posições programáticas dos partidos e com vistas à reeleição pessoal. Assim, compreende-se que as instituições afetam as estratégias de ação enquanto os partidos afetam as preferências dos atores.

Segundo os defensores da tese da ingovernabilidade, o desenho institucional brasileiro combinaria recursos a coligações eleitorais excessivas (dada à inviabilidade de qualquer partido governar com maioria) e legislação permissiva quanto à organização partidária, o que estimularia a existência de partidos sem perfil ideológicoprogramático definido. Os parlamentares teriam estímulos, como a representação proporcional e lista não-ordenada, a agirem de forma personalista e indisciplinada, frente aos partidos políticos que possuiriam um papel pouco relevante (SARTORI, 1993; MAINWARING, 1997). Tais fatores, associados ao forte peso dos governadores na definição da ação dos parlamentares (LAMOUNIER, 1989; MAINWARING \& SAMUELS, 1997; ABRUCIO, 1998), dificultariam a construção de partidos que fossem coerentes nacionalmente, uma vez que estariam presos a questões regionalizadas. Assim, o desenho institucional brasileiro dificultaria que os partidos alcançassem um status nacional de estabilidade e organização em torno de questões programáticas consistentes.

Contrariamente, Braga (2002, p. 23, 180) defende a tese de que os partidos já nascem nacionalizados, uma vez que se constituem sobre perfis político-programáticos nacionais que servem tanto à construção de uma unidade na organização partidária no plano nacional como para definir o espaço de cada partido no espectro ideológico do sistema político brasileiro. Justamente essa "nacionalização" dos partidos políticos colabora para a produção de uma lógica nacional do sistema político segundo parâmetros ideológicos, "facilitando a governabilidade e dando racionalidade mais coletiva às políticas públicas".

Mainwaring (1997) e Kaufman (1998) afirmam que a conformação das instituições políticas, associada a um sistema partidário frágil, seriam fatores que dificultariam a aprovação de medidas de reforma. Kaufman aponta uma série de problemas para a aprovação de medidas de reforma do Estado em sistemas presidencialistas como o Brasil: i) a relação entre os poderes Executivo e Legislativo como um fator de dificuldade, pois os mandatos legislativos independentes enfraqueceriam a tendência dos legisladores de apoiar os líderes do Executivo; ii) o sistema partidário descentralizado e instável do Brasil apresentar-se-ia como paradigma de impedimento à reforma burocrática; iii) a alta burocracia do poder Executivo, como os ministros de Estado, seria barreira de aprovação dado que esta relutaria em entregar o "controle discricionário" sobre fluxos de recursos e contratações.

Também para Mainwaring (1997), a falta de disciplina dos partidos políticos é fator, entre outros, que dificulta os processos de reforma do Estado no Brasil: "Os presidentes brasileiros tiveram dificuldade para realizar a estabilização e a reforma de Estado, em parte devido à combinação de um sistema partidário altamente fragmentado, partidos indisciplinados e federalismo. Essa combinação tornou difícil para os presidentes obter apoio legislativo para a estabilização e para a reforma do Estado. Os presidentes enfrentaram problemas para superar a oposição no Congresso para implementar as reformas mais importantes quando sua popularidade já havia se dissipado" (idem, p. 109).

Sob outra perspectiva, estudos realizados por Abranches (1988), Figueiredo e Limongi (1999) e Santos (2003) demonstraram que tais instituições não necessariamente levariam à ingovernabilidade do país, uma vez que a nova Constituição também muniu o sistema político de instituições capazes de organizar o processo legislativo e permitir ao Executivo aprovar sua agenda de governo. Para os autores, a distribuição de poder é favorável ao Executivo $^{3}$ e o princípio de distribuição de direitos e recursos parlamentares previsto no novo Regimento Interno é partidário e concentrado nas mãos dos líderes. O Presidente congrega apoio à sua agenda de governo por meio de instrumentos capazes de formar coalizões com demais partidos

3 Como a outorga de poderes legislativos ao poder Executivo, que incluem opor veto parcial ou total aos projetos de lei; a faculdade de propor leis, com o monopólio da iniciativa em algumas áreas de políticas públicas (como a reforma da administração pública) e a prerrogativa de editar medidas provisórias, com imediata força de lei. 
políticos e de dirigir a cooperação do Legislativo, restringindo a possibilidade de paralisia decisória, através do "presidencialismo de coalizão".

Tendo por metodologia a perspectiva institucionalista, em especial o modelo partidário (COX \& MCUBBINS, 1993), Figueiredo e Limongi (1999) observaram que o comportamento parlamentar e a relação entre Executivo e Legislativo têm sido orientados por meio dos partidos políticos, justamente as instituições tidas como mais problemáticas pela tese da ingovernabilidade. Os partidos políticos, considerados atores coletivos, funcionariam como o eixo estruturador da centralização parlamentar, em torno do qual definemse e regulam-se direitos e recursos.

Os autores demonstraram que, ao contrário do que afirmava a literatura da tese da ingovernabilidade, o plenário demonstrou ser disciplinado, com a maioria dos deputados votando segundo a orientação do líder do partido. Líderes e liderados têm preferências e interesses políticos semelhantes de acordo com a posição ideológica do partido. A disciplina e a coesão são características encontradas pelos autores, conferindo unidade aos partidos, em oposição à compreensão desses como agrupamentos caóticos ordenados segundo a lógica eleitoral tão somente. Assim, a filiação partidária seria uma "forma ótima" de prever o voto do deputado, pois segundo os autores, apenas é possível pensar na possibilidade de governo de coalizão quando se pode falar em partidos capazes de agir enquanto tais.

Os trabalhos de Figueiredo e Limongi esclarecem o papel das instituições na estruturação dos trabalhos legislativos e nos incentivos à votação disciplinada no Congresso. Resta conhecer um pouco mais sobre o papel dos partidos políticos na definição da ação dos parlamentares por posições favoráveis ou contrárias às propostas apresentadas em plenário, bem como a coerência partidária analisada no eixo do poder Executivo. Quanto a esse último, refiro-me a um padrão nas escolhas por determinadas políticas públicas entre líderes do Executivo nacional e sub-nacional, pertencentes aos mesmos partidos políticos ou a partidos próximos do continuum ideológico nacional.

Quanto ao ordenamento ideológico nacional, segue-se o desenvolvido por Kinzo (1993; 2004) e Figueiredo e Limongi (1999), segundo os quais é possível organizar os principais partidos brasileiros em três classes principais: direita, centro e esquerda, em um continuum ideológico: i) Partido Democrático-Social (PDS), Partido Progressista Renovador (PPR), Partido da Frente Liberal (PFL) (Democratas (DEM)), Partido Trabalhista Brasileiro (PTB); ii) Partido do Movimento Democrático Brasileiro (PMDB), PSDB; iii) Partido Democrático Trabalhista (PDT) e Partido dos Trabalhadores (PT).

É possível observar que embora sob as mesmas instituições, os deputados pertencentes aos diferentes partidos políticos mantêm diferentes posições (positiva/negativa) às propostas do Executivo, conforme a posição ideológica e programática do partido, seguido pela maioria de seus parlamentares (NICOLAU, 2000). Os deputados veriam aí um duplo sentido à fidelidade nas votações: votar de acordo com seu partido respeitando o programa de governo da sigla sob a qual foi eleito e adequar-se ao padrão de relação entre os poderes Executivo-Legislativo admitido internamente. Com isso, além de responder aos anseios de sua base eleitoral (mantendo-se fiel à plataforma partidária) agiria de forma a atingir o objetivo de adquirir sucesso em sua carreira política.

Assim, a observação da votação da Lei das OS, tanto em nível federal (votação simbólica) como no nível estadual (votação nominal), a posição do líder nas votações indica, acredita-se, a posição programática do partido e das coalizões firmadas que ocorrem, por sua vez, entre partidos em posições contíguas do continuum ideológicopartidário.

\section{POSIÇÕES POLÍTICAS FRENTE À PRO- POSTADAS ORGANIZAÇÕES SOCIAIS}

A previsão na Lei das OS de repassar a administração de hospitais, universidades, museus etc. para a gerência de entidades privadas nãolucrativas, qualificadas como OS pelo poder Executivo, gerou fortes discussões. Polarizaramse opiniões e posições políticas.

Os sindicatos profissionais e as associações de classe no setor Saúde ficaram descontentes com as propostas de mudanças das políticas de recursos humanos do governo e, através da mídia e de ação direta com os parlamentares, buscaram influenciar a decisão destes (como foi possível observar claramente nas atas da Assembléia Legislativa de São Paulo). Após a derrota em 
plenário, realizaram proposições ao poder Judiciário para tentar, sem sucesso, reverter a aprovação.

O Conselho Nacional de Saúde (CNS) ${ }^{4}$ também se manifestou a respeito e sua posição foi enfaticamente contrária. Após consulta das atas e deliberações do plenário referentes ao período 1995-2005, constatamos que a maioria dos membros mostrou-se contrária à proposta das OS, mesmo antes da edição da Medida Provisória n. 1 591-1/97, durante as várias reuniões da equipe do governo com os Conselheiros. A resolução n. 223, de 8 de maio de 1997 (BRASIL. MINISTÉRIO DA SAÚDE. CONSELHO NACIONAL DE SAÚDE, 1997) foi a mais clara demonstração dessa postura. Ao homologá-la, o Presidente do CNS e também Ministro da Saúde, Carlos César de Albuquerque, identificou não apenas a posição do CNS, mas a posição do próprio Ministério da Saúde. Em São Paulo, o Conselho Estadual de Saúde (CES) e os conselhos dos municípios a serem atingidos pelo modelo retificaram a posição assumida pelo CNS, manifestando-a em documentos e nas assembléias e audiências públicas realizadas no estado por ocasião do debate e tramitação da proposta.

Ao defender o modelo de OS, o governo FHC e os partidos de sua coalizão argumentaram que seria a saída para os problemas de eficiência e eficácia de serviços sociais até então prestados pelo Estado por meio da administração direta ou indireta. Essa defesa ocorreu em quatro momentos aqui observados: em sua proposição no nível federal; na defesa da proposta no trâmite legislativo em nível federal; em sua adoção em nível estadual e na defesa da proposta no trâmite legislativo estadual ${ }^{5}$.

A proposta das OS está em consonância com o diagnóstico realizado pelo PSDB de que os

\footnotetext{
4 Órgão colegiado compostos por representantes do governo, prestadores de serviço, profissionais de saúde e usuários. Possui, em conjunto com as Conferências de Saúde, caráter consultivo e deliberativo sobre assuntos do setor (cf. BRASIL. MINISTÉRIO DA SAÚDE. CONSELHO NACIONAL DE SAÚDE, 2011).

5 Partidos pertencentes à coalizão do governo FHC: PSDB, PFL, PMDB, PTB, Partido Progressista Brasileiro (PPB), Partido Liberal (PL). Constituíam oposição: PT, Partido Comunista do Brasil (PCdoB), Partido Socialista Brasileiro (PSB), PDT (NICOLAU, 2005).
}

principais problemas enfrentados pela administração pública são a burocracia ineficiente e a ausência de flexibilidade, encontradas no setor. $\mathrm{O}$ argumento oficial do PSDB foi divulgado juntamente com as demais propostas no mesmo sentido, no Plano Diretor de Reforma do Aparelho de Estado (BRASIL. PRESIDÊNCIA DA REPÚBLICA, 1995). A idéia seria o aumento do papel regulatório do Estado em detrimento da prestação direta dos serviços.

O PSDB afirmou no texto de lançamento do partido as suas intenções quanto à reforma do Estado. Desde a epígrafe do texto ("Longe das benesses oficiais, mas perto do pulsar das ruas, nasce o novo partido") é possível perceber a disposição em combater a forma de gerenciar o Estado até então vigente, considerada pelo partido como arcaica, ineficiente, burocrática, empreguista, clientelista e corrupta. Nesse mesmo documento de fundação do PSDB, há um capítulo intitulado "Reforma do Estado", no qual, por duas páginas são indicadas as metas para a reforma das estruturas estatais: "é preciso atacar com firmeza a reforma das estruturas do Estado [...] é preciso também que os recursos aplicados cheguem de fato à população carente, convertendo-se com a máxima eficiência em melhores condições de alimentação, saúde, educação, habitação, transportes coletivos e meio ambiente. Isto requer ação política tenaz do Executivo e do Legislativo, nas esferas da União, dos estados e dos municípios, envolvendo uma ampla reforma do setor público. [...] Mais do que reforma administrativa em sentido estrito, se impõe hoje no Brasil uma reestruturação profunda da máquina do Estado, abrangendo tanto a administração direta como a indireta" (PSDB, 1988, p. 7).

$\mathrm{O}$ texto ainda cita mais duas questões-chave da reforma que empreenderia na década seguinte, com a eleição de FHC, a necessidade de abrir as empresas públicas ao capital privado e a reforma da então nascente Constituição de 1988 , no que diz respeito à remediação da crise fiscal que se desenvolvia.

No programa de governo do PSDB publicado em 1998, no final do primeiro mandato de Fernando Henrique Cardoso, e com vistas à campanha da reeleição, intitulado: "Um novo Estado para uma nova sociedade" no capítulo "Modernização do Estado", o PSDB afirma 
motivos para aprofundar a reforma: "Pelo menos por dois motivos essenciais, o aprofundamento da reforma do Estado é indispensável à construção de uma sociedade mais democrática e participativa: por um lado, o fato indisfarçável de que, em todos os seus níveis, o Estado, do modo como se foi constituindo ao longo da história e da forma como ainda funciona, inibe a democratização das relações entre povo e governo. Não só ele tende a se fechar às iniciativas da sociedade civil; tampouco se julga no dever de lhe prestar contas, como parte inseparável de suas incumbências" (CARDOSO, 1998, p. 139).

Ainda no mesmo programa, indica entre os princípios e diretrizes, a descentralização inclui além do repasse de atribuições de forma hierárquica entre os níveis de governo, a desconcentração do setor público para as organizações da sociedade: "O que acaba com o equívoco de que as coisas ou são estatais ou são privadas - é a das parcerias e transferências. Visa aumentar a qualidade e a produtividade dos serviços prestados - que continuam sendo serviços públicos, embora não mais executados diretamente pelo aparelho estatal. [...] A competição é o princípio que orienta o Estado ao contratar serviços externos. Gastar melhor os recursos públicos, nesse caso, significa também estimular os agentes privados - incluindo as organizações não-governamentais sem fins lucrativos - a competir entre si, a fim de que o dinheiro do contribuinte sirva para pagar o melhor preço possível pelo máximo de qualidade disponível" (idem, p. 140).

Quanto aos temas da reorganização da administração federal e melhoria de gestão, ainda no mesmo documento, afirma-se a intenção do governo em: "descentralizar para a sociedade a gestão de serviços que poderão ser melhor realizados por meio de associações civis sem fins lucrativos (organizações sociais), dotadas de ampla autonomia administrativa, assegurado o acesso a recursos estatais, transferidos via contratos de gestão; [...] expandir a terceirização de serviços" (ibidem).

Em uma apostila lançada em 1990 pelo escritório do então Senador Fernando Henrique Cardoso (CARDOSO, 1990), há um capítulo denominado "Participação sem assembleísmo", no qual o PSDB indica uma diferença que considera básica entre si e o PT no consoante à forma de relacionamento de governo com organizações de base da sociedade: "Porque quer preservar e aperfeiçoar a democracia, o PSDB não pode aceitar o assembleísmo típico do PT. A democracia moderna é participativa, isto é, aberta à participação das organizações de base da sociedade. É um erro, no entanto, invocar essa participação para tentar passar por cima das instituições fundamentais da democracia representativa - o Estado de Direito, o parlamento, o governo legitimamente eleito, o próprio partido político" (idem, p. 31).

O partido rejeita a representação "monoclassista" dos partidos políticos (PT) e afirma que essa visão, aliada à postura de recorrer às associações de base para subverter as instituições levaria a uma degradação do Estado: "A combinação de assembleísmo com a visão mono-classista leva a outra coisa inaceitável para o PSDB: o corporativismo, isto é, a tendência de assumir qualquer reivindicação de qualquer grupo social específico - desde que se enquadre entre os "explorados" - como um direito absoluto. Mesmo reconhecendo que a reivindicação pode ser justa em princípio, o partido político, principalmente quando tem responsabilidades de governo, tem a obrigação de perguntar: quais serão as conseqüências do atendimento dessa reivindicação para o conjunto da sociedade?" (ibidem).

As passagens supra-referidas são citadas com o intuito de questionar posições tomadas na literatura sobre reformas no período. Primeiramente, de que a não-inclusão de uma ampla discussão com organizações de classe e sindicatos no plano de reforma do Estado deu-se por falta de organização interna tanto do governo quanto das associações, como afirmam Melo (2002) e Gaetani (2000). Pois o PSDB, desde sua fundação, embora aceitando o relacionamento com a sociedade civil, não favorece a consulta às organizações de classe e sindicatos, associada à forma de relacionamento petista. Em segundo lugar, é possível perceber que as propostas de reforma do Estado que previam privatizações, desconcentração, abertura ao capital estrangeiro, e reformas da burocracia já estavam presentes desde a fundação do partido, e não se constituíram assim, como saídas para pontos críticos de uma "situação conjuntural". A maioria dos projetos presentes no PDRAE já estava nos primeiros documentos lançados pelo partido. 
Já a proposta das OS não estava ainda elaborada, todavia já estava presente a tônica na reforma do aparelho estatal, na ineficiência da burocracia, na diminuição do número de servidores etc. Em A reforma do aparelho do Estado e as mudanças constitucionais - uma sintese, publicado na página do PSDB (2006), é possível ler suas atuais diretivas para a reforma do Aparelho de Estado, inclusive a clara posição em relação ao tema das OS: "descentralizar e melhorar o desempenho gerencial na prestação de serviços públicos na área social, mediante implantação de organizações sociais, sem vinculação administrativa com o Estado, mas fomentadas com recursos públicos e controladas por contratos de gestão".

O então PFL, inicialmente, colocou-se contrário às propostas de Reforma do Aparelho de Estado, sobretudo referente às reformas constitucionais, pois não possuía interesses diretos na alteração do status quo da burocracia, nem na diminuição dos cargos funcionais, historicamente fontes de clientelismo. Todavia, compunha a base da coalizão do governo e a posição do funcionalismo não constituía uma questão importante para a coalizão de FHC, como chamam a atenção Gaetani e Heredia (2002, p. 6): "Los perdedores potenciales eran los funcionarios públicos, un electorado político sin relevancia particular para la coalición de Cardoso".

Segundo Roma (2002, p. 78), o apoio do PFL recebido pelo PSDB nos dois mandatos de FHC deve-se não a uma aproximação do PSDB ao programa daquele, mas ao contrário. Segundo o autor, o PSDB manteve-se fiel ao seu programa original no qual já aparecia parte das propostas que seriam implantadas no governo FHC, não precisando com isso romper seu programa em relação à abertura ao capital internacional, privatizações, desregulamentação do mercado. Pelo contrário, o PFL apoiou medidas de reforma da máquina pública que provinha recursos à organização do partido em várias comunidades, pois esse apoio garantiria "a manutenção de sua influência no nível federal de governo, observada na indicação de seus filiados para a composição do gabinete ministerial e na liberação de uma parcela expressiva das verbas do orçamento pelo [poder] Executivo para seus Deputados federais". Assim, o PFL, com o intuito de manter-se na coalizão do governo, abriu mão de recursos patrimonialistas e apoiou reformas na administração pública sem, contudo, desviar-se do núcleo de seu programa.

Já no caso do PMDB, este compôs, desde a posse do primeiro governo de FHC, a coalizão de sustentação do governo, construída sobre alianças, entre as quais a distribuição de ministérios. Posicionado mais ao centro do ideário políticoideológico nacional, o PMDB poderia pender a ambos os lados (esquerda ou direita) se não fosse o apoio acordado pelo partido em apoiar as medidas do governo, dado compor a coalizão deste. Assim, os votos dos Parlamentares da sigla foram orientados na posição positiva à proposta.

Os partidos de esquerda no Brasil, embora possuam suas diferenças programáticas, são convencionalmente compreendidos como organizações políticas que defendem os interesses da classe operária, o capital nacional, a importância da posição do Estado no provimento de políticas sociais frente à economia e ao mercado, e contrários à privatização das empresas públicas. Sob o discurso de ser a proposta das OS uma forma de privatização e um meio de o Estado se eximir de suas responsabilidades constitucionais, os partidos PT e PCdoB argumentaram que a "publicização" nada mais seria que uma nova roupagem dada às práticas de privatização dos serviços sociais.

No texto O programa de publicização e as organizações sociais, publicado na página do PT e também em outros textos assinados e divulgados pelo partido, foram tecidas inúmeras críticas à proposta, acusada de inconstitucional pelo partido. Cita-se: “'mascara-se' uma entidade de Direito Público pré-existente em organização social, de modo a conferir-lhe autonomia gerencial e a capacidade de contratar pessoal sem concurso público, realizar compras sem licitação e gerir os recursos públicos sem a necessidade de obediência aos limites da lei orçamentária" (SANTOS, 1998, p. 1-2).

O PT comparou a proposta das OS a outras experiências mal-sucedidas realizadas no setor da Saúde, como o Plano de Atendimento a Saúde (PAS) ${ }^{6}$. O partido indicou a possibilidade de essas novas instituições ficarem a cargo de clientelismo

6 Programa anteriormente implementado por Paulo Maluf (do Partido Progressista (PP)) no município de São Paulo e gerador de inúmeros processos por desvios de recursos públicos, resultando mesmo na desvinculação do município do Sistema Único de Saúde (SUS) em determinado período. 
político e dos interesses privados devido ao formato previsto para essas organizações. Por se tratarem de "instituições cuja relevância para setores menos favorecidos da sociedade as tornem 'butim' cobiçado pela base de sustentação do governo, sempre ávida por cargos públicos e favores". Para o partido, o discurso oficial sobre o aumento da eficiência a ser alcançado por meio das OS não passava de argumento para construir uma possibilidade de satisfazer interesses e privilégios, na forma de privatização de serviços sociais.

Buscando compreender o posicionamento diametralmente oposto do PT e do PSDB perante a proposta, remetemo-nos às questões programáticas desses partidos. Tais questões podem estar ligadas à sua base de sustentação, uma vez que há proximidade do PT com organizações de classe e sindicatos, como a Central Única dos Trabalhadores (CUT), e a defesa dos interesses de setores organizados da sociedade civil, em especial das conquistas sociais e econômicas dos trabalhadores sindicalizados. Por outro lado, está o PSDB com interesse em afirmar-se como a esquerda possível, e não dualista ou "assembleísta" como o PT.

Ainda, quando lançado na Inglaterra, o modelo de desconcentração dos serviços de saúde por meio dos trustes, a matriz do modelo OS, segundo o próprio Ministro Bresser-Pereira (BRASIL, 1997), afirmou-se naquele país em que o modelo nascia para "quebrar a espinha dorsal" do sindicalismo inglês. Por analogia, compreende-se que os partidos de esquerda, que mantêm por bases eleitorais trabalhadores sindicalizados, movimentos sociais e organizações de classe, deviam colocarse contrários à proposição da medida para o Brasil, como de fato o fizeram em relação às OS. E que, em contraposição, o PSDB, que não possuía entre esses sua base eleitoral, se não pretendia unicamente a dissolução do poder dos sindicatos com a proposição do modelo, ao menos com isso nada perderia. Ou seja, ambos os partidos possuíam interesses eleitorais estruturados programaticamente para orientar os atores perante propostas de reforma do Estado, como a observada.

\section{PROPOSIÇÃO E TRAMITAÇÃO LEGIS- LATIVA}

No processo político da aprovação das OS no Congresso Nacional, o Presidente da República utilizou-se do dispositivo da Medida Provisória para lançar o marco legal da proposta, a tempo de iniciar sua implementação mesmo anteriormente à aprovação da Emenda Constitucional (Projeto de Emenda Constitucional n. 143) que tramitava no Congresso. A Medida Provisória (MP) foi reeditada três vezes, até sua conversão em Lei Ordinária, tramitando no Congresso sob regime de urgência, a pedido do poder Executivo. No Congresso a votação deu-se de forma simbólica, em sessão conjunta das duas casas. A proposta da Lei das OS foi previamente acordada entre as lideranças da coalizão, como um componente de um pacote de 11 MPs que tratavam de assuntos administrativos de interesse do poder Executivo e necessárias à reforma administrava (Jornal do Senado, 1998a; 1998b).

A votação foi encaminhada ao plenário da Câmara por meio de votação de simples maioria, por tratar-se da conversão de Medida Provisória em Lei Ordinária, como prevêem os estatutos da casa. Vários parlamentares, favoráveis e contrários à medida discursaram em prol de suas posições. O PSDB defendeu a proposta como uma solução aos problemas do Estado brasileiro e os partidos de esquerda a criticaram por não concordarem com o repasse de atividades que consideravam de responsabilidade do Estado para a iniciativa privada, mesmo que não-lucrativa. Eles indicaram, ainda, a falta de controle por parte do Estado, a possibilidade de manobras escusas e de cobrança por serviços que deveriam ser gratuitos, além de criticarem a forma como foi realizada a votação, com caráter de urgência, o que dificultou a discussão em torno da proposta.

A análise da tramitação demonstra que a centralização dos trabalhos nas mãos dos líderes partidários e sua relação com o poder Executivo, conforme estudado previamente por Figueiredo e Limongi (1999) garantiram a aprovação por votação simbólica, mesmo que de uma questão tão relevante e contraditória como o caso aqui observado. Contando com votos suficientes, dada a coalizão de governo, o Executivo negociou previamente com os líderes na Câmara, passando a votação à ratificação do plenário apenas como uma pro forma. A oposição, em minoria, e dado o caráter de urgência requerido pelo Executivo e do acordo realizado entre as lideranças da coalizão, não encontrou meios de impedir a aprovação da medida e nem ver aprovadas as dez emendas propostas pelo $\mathrm{PT}$ ao plenário.

Não alcançando bloquear a aprovação da Lei n. 9 637/98 dentro do Congresso, o PT, o PDT e 
o PCdoB buscaram outra arena para tentar reverter a derrota no Legislativo. Impetraram, em $1^{\circ}$ de dezembro de 1998, uma Ação Direta de Inconstitucionalidade (ADIN n. 1 923) junto à Procuradoria Geral da República, obtendo a resposta de que a Lei mantinha-se, posto não haver inconstitucionalidade. Também a Federação Nacional dos Médicos (FNM), em representação dirigida à Procuradoria Federal dos Direitos do Cidadão, afirma o caráter privatizante da nova Lei, o enfraquecimento do papel do Estado na prestação dos serviços sociais, o desrespeito à exigência de licitação para os repasses de recursos públicos a empresas privadas. O Conselho Federal de Medicina propôs, em 1997, representação junto ao Ministério Público Federal, requerendo Ação Direta de Inconstitucionalidade da Lei n. 5 980/ 967 , Lei das OS do Estado do Pará, alegando afronta aos dispositivos constitucionais e infraconstitucionais. O Ministério concluiu pelo arquivamento do requerimento.

Na tramitação legislativa da proposta em nível estadual, observada no estado de São Paulo, observou-se comportamento partidário semelhante ao observado em nível nacional. Em 17 de fevereiro de 1998, o Governador Mario Covas (PSDB) enviou à Assembléia Legislativa de São Paulo (Alesp) um projeto de Lei tratando da qualificação de Entidades Filantrópicas como organizações sociais para a área de Saúde. A Lei estadual de OS foi aprovada um mês depois da Lei federal. O Projeto de Lei n. 3, aprovado como Lei Complementar Estadual 846/98, tramitou na Alesp sob pedido de urgência do então Governador.

Textos do jornal $O$ Estado de S. Paulo que tratam sobre o tema das OS e as entrevistas realizadas com a alta burocracia da Secretaria Estadual de Saúde de São Paulo (cf; GOMES, 2003; GUEDES, 2003; NASCIMENTO, 2006) informam que a adoção da proposta deveu-se a questões estruturais vivenciadas naquele momento pelo estado. A existência de hospitais inacabados e o cumprimento da Lei Camata aparecem como principais motivos para a escolha do modelo, buscando colocá-lo como algo diferente das propostas federais de reforma do Estado.

${ }^{7}$ A Lei Estadual n. 5 980/96 foi redigida sobre o projeto de Lei federal sobre o mesmo tema, sendo aprovada anteriormente àquela.
Além da possibilidade constitucional de legislar complementarmente à União no concernente a políticas de saúde, o estado de São Paulo possuía motivos jurídicos que tornavam necessária a promulgação de uma Lei Complementar para que a proposta das OS fosse viável no estado. São eles, a necessidade de regulamentar o acesso ao Tesouro do Estado ${ }^{8}$, a prerrogativa de legislar sobre bens públicos do estado e de sua máquina administrativa (C.F. art. 145, 155, 165), e a necessidade de alteração, por lei específica, do Código de Saúde do estado (Lei Complementar n. 791, de 9 de março de 1995) que não permitia, até então, parcerias com entidades privadas na prestação de serviços de saúde.

Nos quatro meses que separaram a apresentação da proposta e sua votação e aprovação, realizaram-se discussões em plenário e nas comissões, audiências públicas, pedidos de inconstitucionalidade, apresentação de abaixoassinados etc. convocadas por partidos de esquerda e pelo Conselho Estadual de Saúde, com o intuito de aprofundar as discussões e/ou combater a proposta.

No estado de São Paulo a clivagem política manteve-se coerente às posições assumidas pelos partidos em nível federal. A ata da votação do Projeto de Lei (PLC) n. 03/98 é fonte de informação para atestar a disposição dos partidos de esquerda em combater o projeto, e dos partidos de centro e direita em sua defesa. A votação do PLC 03/98 deu-se por voto nominal e maioria absoluta, dado ser Lei Complementar.

Participaram da votação do projeto, salvo emendas, 74 Deputados, sendo 52 votos foram favoráveis (PPR, PFL, PSDB, PMDB, PL, PTB, PDT, Partido da Reconstrução da Ordem Nacional (PRONA) e Partido Popular Socialista (PPS)), 22 votos contrários (PT, PCdoB, PDT, PSB) e três abstenções (PPR). Foram apresentadas ao todo 111 emendas ao projeto de lei, destas foram aprovadas em torno de duas dezenas, que modificaram substantivamente o conteúdo da nova lei (SCHMIDT, 2007). O caso configurou-se de forma que a aprovação do projeto original deu-se pela maioria dos Deputados aliados que votaram

8 Os serviços hospitalares prestados no estado de São Paulo por meio de Organizações Sociais de Saúde têm sido financiados por recursos advindo do Tesouro do Estado, possuindo tabelamento próprio e independente do SUS (cf. NASCIMENTO, 2006). 
de maneira disciplinada contra a votação em massa dos partidos da oposição, o que foi possível observar-se em votação nominal.

A partir de estudos realizados sobre a Alesp, Abrucio, Teixeira e Costa (2001, p. 242) observaram, quanto ao papel dos partidos políticos: "A maior eficácia da coalizão fisiológica do governo no âmbito estadual do que no federal também passa, em segundo lugar pela fragilidade organizacional e institucional dos partidos no nível estadual, cujas estruturas burocráticas de decisão tem pouca influência e capacidade de coerção sobre o comportamento dos deputados, assim como as orientações programáticas tem reduzido impacto na ação dos parlamentares. [...] Quem dá coerência e sentido à ação coletiva dos deputados é o poder Executivo, que constrói a maioria governista atropelando qualquer lógica autônoma de organização partidária".

Nossos estudos, ao contrário do que afirmam os referidos autores, demonstraram um parlamento organizado em termos partidários, com clara posição programática mantida desde o nível federal, cujos deputados votaram, no parlamento estadual, de forma coerente e disciplinada com a formados por partidos de esquerda de um lado e partidos de centro e direita de outro, contaram com $100 \%$ de disciplina de seus membros presentes na votação da Lei das OS. Ou seja, os partidos demonstraram ser, ao menos nesse evento, organizações bem-estruturadas sobre questões programáticas e capazes de ordenar a votação de seus membros segundo essas questões.

Também no nível estadual, o PT buscou, por meio do Ministério Público, a arena do poder posição do partido. Ambos os blocos opositores

Judiciário na tentativa de vetar a Lei das OS e, assim, reverter a derrota no Legislativo. A Procuradoria Geral do Estado concluiu não haver inconstitucionalidade na LCE n. 846/98 (SÃO PAULO. PROCURADORIA GERAL DO ESTADO, 1999, p. 30-55).

\section{ADOÇÃO DO MODELO OS NOS ESTADOS BRASILEIROS}

A Lei Federal n. 9 637/98 indica em seu art. 15 a possibilidade de o poder Executivo dos estados, municípios e Distrito Federal exercer o poder de qualificar, em sua instância, instituições como OS (BRASIL, 1998b). A partir do projeto da Lei Federal $^{9}$ seguiram-se várias legislações estaduais e mesmo municipais específicas. Concordante com as prerrogativas institucionais que outorgam ao poder Executivo a exclusividade de iniciativa legislativa em assuntos referentes à administração pública (BRASIL, 1988, art. 84; SÃO PAULO, 1989 , art. $24, \S 2^{\circ}$ ), compreende-se que a iniciativa de encaminhar o projeto de lei das OS no nível estadual partiu dos governadores.

Contrapondo os dados referentes aos Estados que possuem leis específicas regulamentando a qualificação local de OS, com os partidos dos governadores eleitos entre 1994 (ano anterior ao PDRAE, que lançou a idéia das OS) e 2006, é possível observar que todos os estados em que foi aprovada a legislação sobre OS eram governados, no período da aprovação legislativa, por partidos de orientação ideológica de centro ou direita (PSDB, PMDB, PFL), componentes da coalizão de governo de FHC. Da mesma forma, é possível ainda observar que nenhum estado cujo governo fosse de políticos eleitos por partidos de esquerda (PT, PDT, PSB) adotou a proposta das OS.

QUADRO 1 - LEIS ESTADUAIS DE OS E PARTIDOS NO PODER NO EXECUTIVO ESTADUAL

\begin{tabular}{|l|l|l|}
\hline $\begin{array}{l}\text { UNIDADE DA } \\
\text { FEDERAÇÃO }\end{array}$ & \multicolumn{1}{c|}{$\begin{array}{c}\text { LEGISLAÇÃO ESTADUAL } \\
\text { REFERENTE AS OS }\end{array}$} & GOVERNADORES ELEITOS (1994, 1998 E 2006) \\
\hline \multirow{3}{*}{ Acre } & \multirow{2}{*}{ Não } & 1994 - Oleir Cameli (PPR) \\
& & 1998 - Jorge Viana (PT) \\
& $2002-$ Jorge Viana (PT) \\
\hline
\end{tabular}

9 O projeto de lei da MP n. 1 591-1/97 que já vinha sendo elaborado há mais tempo foi utilizado por alguns estados (Bahia e Pará) para a promulgação de leis estaduais sobre OS antes do lançamento da MP ou da conversão desta em LC (MODESTO, 1997). 


\begin{tabular}{|c|c|c|}
\hline Alagoas & Não & $\begin{array}{l}\text { 1994- Divaldo Suruagy (PMDB) } \\
\text { 1998- Ronaldo Lessa (PSB) } \\
\text { 2002- Ronaldo Lessa (PSB) }\end{array}$ \\
\hline Amapá & Não & $\begin{array}{l}\text { 1994- João Capiberibe (PSB) } \\
\text { 1998- João Capiberibe (PSB) } \\
\text { 2002- Antônio Waldes (PDT) }\end{array}$ \\
\hline Amazonas & Não & $\begin{array}{l}\text { 1994- Amazonino Mendes (PPR) } \\
\text { 1998- Amazonino Mendes (PFL) } \\
\text { 2002- Eduardo Braga (PPS) }\end{array}$ \\
\hline Mato Grosso & Não & $\begin{array}{l}\text { 1994- Dante de Oliveira (PDT) } \\
\text { 1998- Dante de Oliveira (PSDB) } \\
\text { 2002- Blairo Maggi (PPS) }\end{array}$ \\
\hline $\begin{array}{l}\text { Mato Grosso do } \\
\text { Sul }\end{array}$ & Não & $\begin{array}{l}\text { 1994- Wilson Martins (PMDB) } \\
\text { 1998- José Miranda (Zeca do PT) (PT) } \\
\text { 2002- José Miranda (Zeca do PT) (PT) }\end{array}$ \\
\hline Minas Gerais & Não & $\begin{array}{l}\text { 1994- Eduardo Azeredo (PSDB) } \\
\text { 1998- Itamar Franco (PMDB) } \\
\text { 2002- Aécio Neves (PSDB) }\end{array}$ \\
\hline Paraíba & Não & $\begin{array}{l}\text { 1994- Antônio Mariz (PMDB) } \\
\text { 1998- Ze Maranhão (PMDB) } \\
\text { 2002- Cássio Cunha Lima (PSDB) }\end{array}$ \\
\hline Paraná & Não & $\begin{array}{l}\text { 1994- Jaime Lerner (PDT) } \\
\text { 1998- Jaime Lerner (PFL) } \\
\text { 2002- Roberto Requião (PMDB) }\end{array}$ \\
\hline Piauí & Não & $\begin{array}{l}\text { 1994- Francisco Sousa (PMDB) } \\
\text { 1998- Francisco Souza (PMDB) } \\
\text { 2002- Wellington Dias (PT) }\end{array}$ \\
\hline Rio de Janeiro & Não & $\begin{array}{l}\text { 1994- Marcello Alencar (PSDB) } \\
\text { 1998- Anthny Garotinho (PDT) } \\
\text { 2002- Rosinha Garotinho (PSB) }\end{array}$ \\
\hline $\begin{array}{l}\text { Rio Grande do } \\
\text { Norte }\end{array}$ & Não & $\begin{array}{l}\text { 1994- Garibaldi Alves (PMDB) } \\
\text { 1998- Garibaldi Alves (PMDB) } \\
\text { 2002- Vilma Maria de Faria (PSB) }\end{array}$ \\
\hline $\begin{array}{l}\text { Rio Grande do } \\
\text { Sul }\end{array}$ & Não & $\begin{array}{l}\text { 1994- Antônio Britto (PMDB) } \\
\text { 1998- Olívio Dutra (PT) } \\
\text { 2002- Germano Rigotto (PMDB) }\end{array}$ \\
\hline Rondônia & Não & $\begin{array}{l}\text { 1994- Valdir Raupp (PMDB) } \\
\text { 1998- Bianco (PFL) } \\
\text { 2002- Ivo Cassol (PSDB) }\end{array}$ \\
\hline Roraima & Não & $\begin{array}{l}\text { 1994- Paulo Affonso Vieira (PMDB) } \\
\text { 1998- Espiridião Amim (PPB) } \\
\text { 2002- Luiz Henrique da Silveira (PMDB) }\end{array}$ \\
\hline Tocantins & Não & $\begin{array}{l}\text { 1994- Siqueira Campos (PPR) } \\
\text { 1998- Siqueira Campos (PFL) } \\
\text { 2002- Marcello Miranda (PFL) }\end{array}$ \\
\hline Maranhão & $\begin{array}{l}\text { Lei } n .7066 \text {, de } 3 \text { de fevereiro } \\
\text { de } 1998\end{array}$ & $\begin{array}{l}1994 \text { - Roseana Sarney (PFL) } \\
1998 \text { - Roseana Sarney (PFL) } \\
1999 \text { - José Tavares (PFL) }\end{array}$ \\
\hline Sergipe & $\begin{array}{l}\text { Lei n. } 5217 \text {, de } 15 \text { de } \\
\text { dezembro de } 2003\end{array}$ & $\begin{array}{l}\text { 1994- Albano Franco (PSDB) } \\
\text { 1998- Albano Franco (PSDB) } \\
2002 \text { - João Alves Filho (PFL) }\end{array}$ \\
\hline
\end{tabular}




\begin{tabular}{|c|c|c|}
\hline Distrito Federal & $\begin{array}{l}\text { Lei n. } 2415 \text {, de } 6 \text { de julho de } \\
1999\end{array}$ & $\begin{array}{l}1994 \text { - Cristóvam Buarque (PT) } \\
1998 \text { - Joaquim Roriz (PMDB) } \\
2002 \text { - Joaquim Roriz (PMDB) }\end{array}$ \\
\hline Goiás & $\begin{array}{l}\text { Lei n. } 15503 \text {, de } 28 \text { de } \\
\text { dezembro de } 2005 .\end{array}$ & $\begin{array}{l}1994 \text { - Luiz A. Vilela (PMDB) } \\
1998 \text { - Marconi Perillo (PSDB) } \\
2002 \text { - Marconi Perillo Jr (PSDB) }\end{array}$ \\
\hline Ceará & $\begin{array}{l}\text { Lei n. } 12781 \text {, de } 30 \text { de } \\
\text { dezembro de } 1997\end{array}$ & $\begin{array}{l}1994 \text { - Tasso Jereissati (PSDB) } \\
1998 \text { - Tasso Jereissati (PSDB) } \\
2002 \text { - Lúcio Alcântara (PSDB) }\end{array}$ \\
\hline São Paulo & $\begin{array}{l}\text { Lei Complementar n. 846, de } 4 \\
\text { de junho de } 1998\end{array}$ & $\begin{array}{l}\text { 1994- Mario Covas (PSDB) } \\
\text { 1998- Mario Covas (PSDB) } \\
\text { 2002- Geraldo Alkmin (PSDB) }\end{array}$ \\
\hline Espírito Santo & $\begin{array}{l}\text { Lei Complementar n. 158, de } 1 \\
\text { de julho de } 1999\end{array}$ & $\begin{array}{l}1994 \text { - Vitor Buaiz (PT) } \\
1998 \text { - José Inácio (PSDB) } \\
2002 \text { - Paulo Hartung (PSB) }\end{array}$ \\
\hline Bahia & $\begin{array}{l}\text { Decreto n. } 8890 \text { de } 21 \text { de } \\
\text { janeiro de } 2004 \\
\text { Lei n. } 8647 \text { de } 29 \text { de julho de } \\
2003\end{array}$ & $\begin{array}{l}1994 \text { - Paulo Souto (PFL) } \\
1998 \text { - César Borges (PFL) } \\
2002 \text { - Paulo Souto (PFL) }\end{array}$ \\
\hline Santa Catarina & $\begin{array}{l}\text { Decreto n. } 3294 \text {, de } 15 \text { de } \\
\text { julho de } 2005 \\
\text { Lei n. } 12 \text { 929, de } 4 \text { de fevereiro } \\
\text { de } 2004\end{array}$ & $\begin{array}{l}1994 \text { - Paulo Afonso Vieira (PMDB) } \\
1998 \text { - Esperidião Amin (PPB) } \\
2002 \text { - Luiz Henrique da Silveira (PMDB) }\end{array}$ \\
\hline Pernambuco & $\begin{array}{l}\text { Decreto n. } 23046 \text {, de } 19 \text { de } \\
\text { fevereiro de } 2001 \\
\text { Lei n. } 11743 \text { de } 20 \text { de janeiro } \\
\text { de } 2000\end{array}$ & $\begin{array}{l}1994 \text { - Miguel Arraes (PSB) } \\
1998 \text { - Jarbas Vasconcelos (PMDB) } \\
2002 \text { - JarbasVasconcelos (PMDB) }\end{array}$ \\
\hline Pará & $\begin{array}{l}\text { Decreto n. } 3876 \text {, de } 21 \text { de } \\
\text { janeiro de } 2000 \\
\text { Lei n. } 5980 \text {, de } 19 \text { de julho de } \\
1996\end{array}$ & $\begin{array}{l}1994 \text { - Almir Gabriel (PSDB) } \\
1998 \text { - Almir Gabriel (PSDB) } \\
2002 \text { - Simão Jatene (PSDB) }\end{array}$ \\
\hline
\end{tabular}

FONTE: a autora, a partir de Bahia (s/d), Ceará (s/d), Distrito Federal (s/d), Espírito Santo (s/d), Goiás (s/d), Maranhão (s/d), Pará (s/d), Pernambuco (s/d), São Paulo (s/d) e Sergipe (s/d).

NOTA: os nomes de governadores em itálico correspondem aos promulgadores ou sancionadores das respectivas legislações estaduais sobre OS.

A literatura que trata sobre o tema da adoção de medidas de reforma fiscal e administrativa propostas pelo projeto de reforma do Estado (ABRUCIO, 1997; 2005; GAETANI, 2000; ABRUCIO \& GAETANI, 2006) afirma que essas medidas foram adotadas pelos estados segundo suas condições econômico-financeiras em relação ao cumprimento da responsabilidade fiscal.

Abrucio (1998) compreende que a adesão dos estados às medidas de cunho "modernizantes" da administração pública seria explicada pela tentativa de adequar sua situação administrativo-econômica frente à legislação vigente (Lei Camata-Lei de Responsabilidade Fiscal) e diante da possibilidade de negociar a dívida pública dos estados com a União.
Para Gaetani (2000, p. 6) os estados uniramse ao projeto de reformas difundido desde o nível federal devido à atuação de Bresser-Pereira, que teria convencido os governadores da importância das reformas para melhorar sua situação local: "los gobernadores se unieron al equipo económico como aliados del proyecto de Bresser-Pereira, porque necesitaban expandir su espacio de maniobra para promover ajustes regionales".

Para Abrucio e Gaetani (2006, p. 24) os estados teriam sido motivados a aderir aos projetos de reforma, conforme difundidos pelo governo federal, devido a quatro fatores interligados: "a crise financeira dos governos estaduais e a cons- 
trução de uma coalizão ${ }^{10}$ e de instituições próajuste fiscal; 2 . a propagação das idéias da Nova Gestão Pública após 1995, com o esforço recente de técnicos com passagem pelo Governo Federal, os quais, sobretudo desde 2003, migraram para os governos estaduais; 3. disseminação de boas práticas e inovações administrativas pelo País; fortalecimento de fóruns federativos inter-estaduais, como o Conselho de Secretários Estaduais de Administração (Consad); 4. o processo de Construção de uma rede entre a União e os estados em prol do Pnage [Programa Nacional de Apoio à Gestão Administrativa dos Estados Brasileiros], em termos de diagnóstico, montagem e negociação do programa".

Acredita-se que resta um aspecto a ser considerado quanto à adesão dos estados às medidas de reforma: a dimensão político-partidária. Os resultados demonstram que apenas estados governados por partidos de centro e direita aderiram à proposta e que nenhum estado governado por partidos de esquerda o fez. Essa constatação permite-nos sugerir que a adesão ou não a medidas de reforma propostas em nível federal poderia ser melhor compreendida se observados os parâmetros partidários no processo decisório.

Dado ser o modelo de OS proposto para aumentar a eficiência e diminuir os gastos públicos com funcionalismo (ativo e inativo), espera-se que os estados que buscassem aderir ao modelo fossem justamente aqueles que tivessem maior dívida pública e/ou maior correlação entre as despesas com pessoal e receita líquida. O cumprimento da Lei Camata, válida para o período de 1995 a 2000, exigia que os estados gastassem, no máximo, $60 \%$ de sua receita líquida com funcionalismo. Para o segundo período, a partir de 2001, a Lei de Responsabilidade Fiscal manteve tais índices, especificando ainda as cotas de gastos para cada nível administrativo do governo, fixando para o nível executivo o teto máximo de $49 \%$ da receita líquida para gastos com pessoal.

TABELA 1 - LEIS ESTADUAIS E RAZÃO DA DESPESA COM PESSOAL E RECEITA LÍQUIDA DOS ESTADOS

\begin{tabular}{|c|c|c|c|}
\hline \multirow{2}{*}{$\begin{array}{l}\text { UNIDADE DA } \\
\text { FEDERAÇÃO }\end{array}$} & \multirow{2}{*}{$\begin{array}{l}\text { LEI LOCAL } \\
\text { SOBRE OS }\end{array}$} & \multicolumn{2}{|c|}{$\begin{array}{c}\text { MÉDIA \% DA RAZÃO DE DESPESA TOTAL COM } \\
\text { PESSOAL/RECEITA LIIQUIDA }\end{array}$} \\
\hline & & 1995-1997 & 2001-2004 \\
\hline Bahia & SIM (2002) & 57,93 & 41,38 \\
\hline Goiás & SIM (2002) & 72,13 & 44,50 \\
\hline Santa Catarina & SIM (2002) & 66,97 & 46,53 \\
\hline Sergipe & SIM (2002) & 69,47 & 45,98 \\
\hline Ceará & SIM (1998) & 51,63 & 40,68 \\
\hline Distrito Federal & SIM (1998) & 79,07 & 32,65 \\
\hline Espírito Santo & SIM (1998) & 70,77 & 37,86 \\
\hline Maranhão & SIM (1998) & 63,80 & 44,17 \\
\hline São Paulo & SIM (1998) & 57,87 & 46,85 \\
\hline Pará & SIM $(1994,1998)$ & 67,13 & 43,52 \\
\hline Pernambuco & SIM (1994) & 79,67 & 46,56 \\
\hline \multicolumn{2}{|c|}{$\begin{array}{l}\text { Total de estados com índice superior ao } \\
\text { exigido }(60 \% ; 49 \%)\end{array}$} & $73 \%$ & $0 \%$ \\
\hline Acre & NÃO & 71,67 & 47,46 \\
\hline Alagoas & NÃO & 80,60 & 46,98 \\
\hline Amapá & NÃO & 67,73 & 36,40 \\
\hline Amazonas & NÃO & 44,63 & 40,56 \\
\hline Mato Grosso & NÃO & 71,10 & 37,14 \\
\hline
\end{tabular}

10 A coalizão a que se referem os autores diz respeito a uma classe de empreendedores de políticas, burocratas e policy-makers com uma mesma "visão de mundo" orientada para uma nova gestão pública. 


\begin{tabular}{|llcl|}
\hline Mato Grosso do Sul & NÃO & 68,07 & 39,43 \\
Minas Gerais & NÃO & 68,70 & 57,64 \\
Paraíba & NÃO & 58,17 & 47,80 \\
Paraná & NÃO & 69,03 & 46,63 \\
Piauí & NÃO & 78,53 & 49,22 \\
Rio de Janeiro & NÃO & 110,27 & 35,80 \\
Rio Grande do Norte & NÃO & 78,50 & 47,38 \\
Rio Grande do Sul & NÃO & 80,57 & 48,15 \\
Rondônia & NÃO & 82,00 & 36,43 \\
Roraima & NÃO & 19,03 & 29,74 \\
Tocantins & NÃO & 45,03 & 36,99 \\
Total de estados com índice superior ao & $75 \%$ & $12,5 \%$ \\
exigido (60\%; 49\%) & & $72 \%$ \\
\hline
\end{tabular}

FONTE: a autora, a partir de Dataíndice (s/d), Brasil. Supremo Tribunal Federal (2004), Mendes (2006) e Yoshida (2006).

NOTAS: 1. Para o período 1995-1997: trabalhou-se com os dados disponíveis sobre gastos com pessoal e dívida líquida dos estados na literatura especializada. Aproximou-se 1998 ao ano anterior mais próximo de que se dispunha de dados (1997).

2. Para o período 2001-2004: o limite com gastos total com pessoal exigido pela Lei Camata (válida entre 1995 e 2000) é de 60\%. Os gastos com o poder Executivo estadual, segundo a Lei de Responsabilidade Fiscal (válida a partir de 2001), são de $49 \%$.

Os dados apresentados demonstram que dos estados que aderiram à proposta das OS no primeiro período, $71 \%$ estavam acima do limite de $60 \%$ exigido pela Lei Camata com um índice de extrapolação de 10,23\%, em média. No mesmo período, $75 \%$ dos estados que não aderiram à proposta estavam acima do limite exigido, com um índice de extrapolação de 18,75\%, em média. Dos estados que aderiram à proposta no período seguinte (2001 a 2005), todos estavam abaixo do limite exigido pela lei. Já entre os estados que não aderiram à proposta nesse período, dois estavam acima do limite de $49 \%$ com gastos com o pessoal do Executivo.

A seguir apresentam-se dados que comparam a existência de leis estaduais sobre OS versus a razão entre a dívida dos estados por sua receita líquida. Segundo a literatura, esperava-se encontrar que estados com dívida maior aderissem ao modelo, bem como esperava-se que estados que houvessem aderido ao modelo tivessem uma diminuição mais acentuada em suas dívidas no período subseqüente.

TABELA2 - LEIS ESTADUAIS DE OS EA RAZÃO ENTRE A DÍVIDA E RECEITALÍQUIDA DOS ESTADOS

\begin{tabular}{|c|c|c|c|c|c|c|c|c|c|}
\hline \multirow[t]{2}{*}{$\begin{array}{l}\text { UNIDADE DA } \\
\text { FEDERAÇÃOO }\end{array}$} & \multirow[t]{2}{*}{$\begin{array}{c}\text { LEI } \\
\text { ESTADUAL } \\
\text { DE OS }\end{array}$} & \multicolumn{7}{|c|}{$\begin{array}{c}\text { \% DA RAZÃO ENTRE DÍVIDA ESTADUAL E RECEITA } \\
\text { CORRENTE LÍQUIDA DOS ESTADOS } \\
\text { DESTACADO O ANO DA APROVACAO DA LEI } \\
\text { ESTADUAL DE OS }\end{array}$} & \multirow{2}{*}{$\begin{array}{l}\text { EVOLUÇÃO } \\
\text { DÍVIDA/ } \\
\text { RECEITA } \\
(1996-2005) \\
\end{array}$} \\
\hline & & 1996 & 2000 & 2001 & 2002 & 2003 & 2004 & 2005 & \\
\hline Bahia & SIM & 1,56 & 1,64 & 1,71 & 1,82 & 1,63 & 1,42 & 1,30 & 0,26 \\
\hline Ceará & SIM & 1,14 & 0,87 & 0,94 & 1,18 & 1,06 & 0,92 & 0,79 & 0,35 \\
\hline Distrito Federal & SIM & 0,22 & 0,36 & 0,35 & 0,40 & 0,36 & 0,27 & 0,25 & $-0,03$ \\
\hline Espírito Santo & SIM & 1,07 & 0,98 & 0,83 & 1,16 & 1,02 & 0,73 & 0,50 & 0,57 \\
\hline Goiás & SIM & 3,64 & 3,13 & 2,81 & 2,77 & 2,40 & 2,21 & 2,05 & 1,59 \\
\hline Maranhão & SIM & 1,82 & 2,58 & 2,10 & 2,73 & 2,22 & 1,74 & 1,55 & 0,27 \\
\hline Pará & SIM & 0,76 & 0,57 & 0,63 & 0,76 & 0,61 & 0,60 & 0,54 & 0,22 \\
\hline Pernambuco & SIM & 1,41 & 0,86 & 1,12 & 1,25 & 1,17 & 1,04 & 0,95 & 0,46 \\
\hline
\end{tabular}




\begin{tabular}{|c|c|c|c|c|c|c|c|c|c|}
\hline Santa Catarina & SIM & 1,23 & 1,83 & 1,45 & 1,95 & 1,67 & 1,63 & ND & $-0,04$ \\
\hline São Paulo & SIM & 2,63 & 1,93 & 1,97 & 2,27 & 2,24 & 2,38 & 2,11 & 0,52 \\
\hline \multirow[t]{2}{*}{ Sergipe } & SIM & 1,33 & 0,88 & 0,78 & 0,73 & 0,68 & 0,65 & 0,53 & 0,8 \\
\hline & & & & & & & & & Média $=0,45$ \\
\hline Acre & NÃO & 1,62 & 1,04 & 0,83 & 0,73 & 0,68 & 0,62 & 0,49 & 1,13 \\
\hline Alagoas & NÃO & 1,56 & 2,23 & 1,78 & 2,36 & 2,77 & 2,64 & 2,35 & $-0,79$ \\
\hline Amapá & NÃO & 0,35 & 0,05 & 0,05 & 0,28 & 0,28 & 0,23 & 0,12 & 0,23 \\
\hline Amazonas & NÃO & 0,76 & 1,00 & 0,69 & 0,67 & 0,56 & 0,45 & 0,31 & 0,45 \\
\hline Mato Grosso & NÃO & 2,74 & 2,50 & 1,97 & 1,59 & 1,76 & 1,30 & 1,18 & 1,56 \\
\hline $\begin{array}{l}\text { Mato Grosso } \\
\text { do Sul }\end{array}$ & NÃO & 3,04 & 3,10 & 2,94 & 3,10 & 2,67 & 2,33 & 2,14 & 0,90 \\
\hline Minas Gerais & NÃO & 2,18 & 1,41 & 2,34 & 2,63 & 2,43 & 2,24 & 2,04 & 0,14 \\
\hline Paraíba & NÃO & 1,33 & 1,53 & 1,10 & 1,42 & 1,17 & 1,08 & 0,94 & 0,39 \\
\hline Paraná & NÃO & 0,99 & 1,29 & 1,34 & 1,24 & 1,05 & 1,10 & ND & $-0,11$ \\
\hline Piauí & NÃO & 2,11 & 1,73 & 1,74 & 1,64 & 1,52 & 1,42 & 1,12 & 0,99 \\
\hline Rio de Janeiro & NÃO & 1,81 & 2,07 & 1,90 & 2,35 & 2,01 & 2,04 & 1,94 & $-0,13$ \\
\hline $\begin{array}{l}\text { Rio Grande do } \\
\text { Norte }\end{array}$ & NÃO & 1,00 & 0,71 & 0,54 & 0,65 & 0,53 & 0,38 & 0,39 & 0.61 \\
\hline $\begin{array}{l}\text { Rio Grande do } \\
\text { Sul }\end{array}$ & NÃO & 2,04 & 2,66 & 2,51 & 2,79 & 2,80 & 2,83 & 2,78 & $-0,74$ \\
\hline Rondônia & NÃO & 2,77 & 1,11 & 1,05 & 1,45 & 1,21 & 1,06 & 1,00 & 1,77 \\
\hline Roraima & NÃO & 0,19 & 0,31 & 0,28 & 0,35 & 0,43 & 0,04 & 0,08 & 0,11 \\
\hline \multirow[t]{2}{*}{ Tocantins } & NÃO & 1,04 & 0,35 & 0,27 & 0,37 & 0,26 & 0,35 & $-0,01$ & 1,05 \\
\hline & & & & & & & & & Média $=0,47$ \\
\hline Médias anuais & & 1,57 & 1,43 & 1,33 & 1,50 & 1,37 & 1,24 & 0,71 & \\
\hline
\end{tabular}

NOTA: ND: não disponível.

A análise dos dados apresentados acima demonstra que dos estados que aderiram à proposta das OS, menos da metade (45\%) estavam acima do índice médio do período em que a lei foi aprovada em cada um dos estados. Quanto à diminuição da razão entre a dívida e receita líquida, os estados que aderiram ao modelo apresentaram em média um decréscimo de $0,45 \%$. Já os estados que não aderiram ao modelo, ou seja, não aprovaram legislações estaduais sobre OS, apresentaram em média um decréscimo de 0,47\%. Em geral os estados diminuíram suas dívidas públicas entre o período de 1996 e 2005, todavia esse decréscimo não foi maior entre os que assumiram a possibilidade de desconcentrar a prestação de serviços públicos por meio de organizações sociais.

Observando os resultados apresentados no Quadro 1 e nas tabelas 1 e 2 é possível perceber que o cumprimento ou não da Lei Camata e Lei de Responsabilidade fiscal não são fatores que explicam a adesão ao modelo das OS. Da mesma for- ma, não há relação entre o tamanho da dívida pública dos estados e a aprovação de Lei de OS.

Por outro lado, percebe-se que pertencer a um partido de centro ou direita é condição necessária (mesmo que não suficiente) para explicar por que houve adoção da proposta pelo estado. Também demonstra que, o fato de o governo estadual pertencer a um governo de esquerda é condição suficiente para explicar porque o estado não aderiu à proposta.

Compreende-se que, embora pudesse haver motivos econômicos e financeiros para que os governadores apoiassem medidas de reforma administrativas (ABRUCIO \& COSTA, 1998; GAETANI, 2000; GAETANI \& HEREDIA, 2002; MELO, 2002), como era a proposta das organizações sociais, a adoção do modelo deu-se apenas entre governadores de centro e direita, pertencentes à coalizão do governo federal (PSDB), ou seja, aspectos partidários foram determinantes. 


\section{CONSIDERAÇÕES FINAIS}

Através do estudo sobre uma nova legislação no contexto da segunda onda de reformas no Brasil, por meio da observação do comportamento político e do papel das instituições, esperamos ter demonstrado que, ao menos para o caso analisado, as inferências sobre a inoperância do sistema político brasileiro, em parte devido à "frágil" organização partidária no país, não são aplicáveis.

Os partidos demonstraram agir de forma coesa, disciplinada e programaticamente orientada tanto na arena parlamentar quando no poder Executivo, de acordo com suas plataformas de governo que os diferenciam. Ao menos os principais partidos brasileiros possuíram, para o caso analisado, uma posição definida que foi seguida pela maioria de seus membros. Essa consideração serve de eixo explicativo para a cadeia decisória iniciada com a proposição em nível nacional, sua adoção pelos estados e sua aprovação no parlamento estadual. Em cada nível decisório, o posicionamento partidário permeia a relação dos atores com as instituições aí localizadas.

O posicionamento partidário pôde ser observado na orientação da preferência do poder Executivo federal na proposição do modelo das OS como meio de desconcentrar a prestação dos serviços públicos e reduzir o tamanho do aparelho estatal, ao lado de propostas diversas como a privatização e terceirização, questões programáticas do PSDB, partido do então Presidente da República. As medidas de reforma que previam a desestatização, a diminuição dos servidores públicos e, com isso, a diminuição da organização no setor (organizações de classe, sindicatos) foram combatidas por partidos de esquerda, tradicionalmente ligados à defesa dos interesses dessas classes e do maior peso do Estado na provisão de serviços sociais.

Os pólos entre as posições partidárias variaram entre o PSDB, propositor do projeto das OS, e de outro lado o PT, como maior partido que combateu a medida. Os partidos da coligação adequaram-se à agenda de governo por esta não divergir claramente das suas próprias e para permanecer na coligação de governo.
No Congresso Nacional, a votação deu-se em turno único, unindo as duas casas. Dispondo o governo de uma maioria parlamentar conformada por sua base de coalizão e dado o caráter concentrado de decisão, mesmo uma questão que contou com tamanha divergência alcançou a aprovação. No âmbito parlamentar estadual (São Paulo) manteve-se a mesma clivagem partidária em relação à proposta, indicando coerência na posição dos partidos, claramente observada no processo de votação nominal.

Também quanto à adoção do modelo pelos Executivos estaduais, houve orientação partidária na ação dos governadores. Apenas estados governados por partidos de centro ou direita do continuum ideológico partidário nacional, componentes em nível federal da coalizão de sustentação do governo aderiram à proposta e, por outro lado, nenhum governador eleito sob a sigla de partidos de esquerda aderiu ao novo modelo. Tal constatação, aliada aos dados sobre as condições fiscais e econômicoadministrativas permite concluir que a adesão ou não a medidas de reforma propostas em nível federal poderia ser melhor compreendida se analisados os parâmetros partidários.

Em cada uma das arenas observadas, os atores organizaram suas estratégias segundo as disposições institucionais. O Executivo definiu segundo seu interesse propor ou não a medida ao plenário, uma vez que possui prerrogativa de exclusividade sobre o assunto e poder de agenda para tal. Os parlamentares, organizados segundo as regras internas ao parlamento, votaram segundo parâmetros partidários. A oposição, quando dispôs de maior apoio político (estado de São Paulo), logrou aprovar emendas ao projeto original enviado pelo Executivo, pois dada à inviabilidade de rejeitá-lo por completo, buscou aproximá-lo de suas preferências programáticas. As organizações de classe, mesmo contrárias à medida, não encontrararam meio de bloquear sua aprovação, pois a estrutura institucional brasileira não prevê possibilidade formal de veto a esses atores além de buscar influenciar previamente os legisladores ou buscar remediar legislações já aprovadas por meio de proposições junto às instâncias do poder Judiciário.

Vera Viviane Schmidt (veraviviane@usp.br) é Graduada em Ciências Sociais pela Universidade Federal do Paraná (UFPR), Especialista em Sociologia Política (UFPR), Mestre e Doutoranda em Ciência Política pela Universidade de São Paulo (USP) e Professora da Fundação Getúlio Vargas (FGV). 


\section{REFERÊNCIAS BIBLIOGRÁFICAS}

ABRANCHES, S. H. 1988. Presidencialismo de coalizão: o dilema institucional brasileiro. $D a$ dos, Rio de Janeiro, v. 31, n. 1, p. 5-34.

ABRUCIO, F. L. 1988. Os barões da federação: o poder dos governadores no Brasil pós-autoritário. São Paulo: Hucitec.

1997. O impacto do modelo gerencial da administração pública. Um breve estudo sobre a experiência internacional recente. Cadernos ENAP, Brasília, n. 10. Disponível em: http:// www.enap.gov.br/index.php?option $=\mathrm{com}_{-}$ docman\&task $=$ doc_download\&gid $=1614$. Acesso em: 15.set.2011.

2005. Reforma do Estado no federalismo brasileiro: a situação das administrações públicas estaduais. Revista de Administração Pública, Rio de Janeiro, v. 39, n. 2, p. 401-420, mar.-abr. Disponível em: http://ocotidiano daburocracia.com.br/files/Abrucio.pdf. Acesso em: 15.set.2011.

ABRUCIO, F. L. \& COSTA, V. M. 1988. Reforma do Estado e o contexto federativo brasileiro. São Paulo: Fundação Konrad Adenauer.

ABRUCIO, F. L. \& GAETANI, F. 2006. Avanços e perspectivas da gestão pública nos estados: agenda, aprendizado e coalizões. In: Avanços e perspectivas da gestão pública nos estados. Brasília: Conselho Nacional dos Secretários de Estado de Administração. Disponivel em: http://www.portalct.com.br/blogs/ gestaopublica/administracao/files/files/ AVAN\%C3\%87OS\%20E\%20PERSPECTIVAS $\%$ 20DA $\% 20$ GEST $\%$ C3\%83O $\% 20 \mathrm{P} \% \mathrm{C} 3 \% 9$ ABLICA $\% 20$ NOS\%20ESTADOS\%20AGENDA ,\%20APRENDIZADO $\% 20 \mathrm{E} \% 20 \mathrm{COALIZ} \%$ C3\%83O.pdf. Acesso em: 15.set.2011.

BRAGA, M. 2002. O processo partidário-eleitoral brasileiro: padrões de competição política: 1982-2002. São Paulo. Tese (Doutorado em Ciência Política). Universidade de São Paulo.

CARDOSO, F. H. 1990. A social-democracia: o que é, o que propõe para o Brasil. São Paulo: s/n. Disponivel em: http://www2.psdb.org.br/ wp-content/uploads/biblioteca/36575470.pdf. Acesso em: 15.set.2011.
1998. Avança, Brasil: proposta de governo. Brasília: Partido da Social-Democracia Brasileira. Disponivel em: http://www. google.com.br/url?sa=t\&source=web\&cd $=1$ \&ved $=0 \mathrm{CB} 0 \mathrm{QFj}$ AA\&url $=\mathrm{http} \% 3 \mathrm{~A} \% 2 \mathrm{~F} \%$ 2Fwww.bvce.org\%2FDownloadArquivo.asp\% 3FArquivo\%3DCARDOSO_Avanca_Brasil Proposta de governo.pdf $22 \quad 10 \quad 2008 \quad 17 \quad \overline{4} 744 . p d \overline{d f}$ \&rct $=\mathrm{j} \& \mathrm{q}=$ Avan $\% \mathrm{C} 3 \% \overline{\mathrm{A}} 7 \mathrm{a} \% 2 \mathrm{C} \% 20 \mathrm{Brasil} \%$ $3 \mathrm{~A} \% 20$ proposta $\% 20 \mathrm{de} \% 20$ governo\&ei $=$ QACfTv6zNoXg0QHgsfmCCQ\&usg= AFQjCNFgZmwmW-5KSYxDUnzv4s NmGIz0Zg. Acesso em: 15.set.2011.

CARNEIRO JR., N. 2002. O setor público nãoestatal: as organizações locais como possibilidades e limites na gestão pública da saúde. São Paulo. Tese (Doutorado em Saúde Pública). Universidade de São Paulo.

CASTRO, M. F. 1997. O Supremo Tribunal Federal e a judicialização da política. Revista Brasileira de Ciências Sociais, São Paulo, v. 12, n. 34, jul. Disponivel em: http://www.anpocs. org.br/portal/publicacoes/rbcs_00_34/ rbcs34 09.htm. Acesso em: 15.set.2011.

COX, G. \& MCCUBBINS, M. 1993. Legislative Leviathan. Party Government in the House. Berkeley: University of California.

FIGUEIREDO, A. \& LIMONGI, F. 1999. Executivo e Legislativo na nova ordem constitucional. Rio de Janeiro: Fundação Getúlio Vargas.

GAETANI, F. \& HEREDIA, B. 2000. La intrigante reforma administrativa brasileña. Revista del CLAD Reforma y Democracia, Caracas, n. 16, p. 1-14, feb. Disponivel em: http:/ /www.bresserpereira.org.br/Documents/ MARE/CLAD/2000Gaetani.pdf. Acesso em: 15.set.2011.

2002. La Economía Política de la reforma del servicio civil en Brasil: los años de Cardoso. Documento preparado para a Red de Gestión y Transparencia del Diálogo Regional del Banco Interamericano de Desarrollo. Disponivel em: http://idbdocs.iadb.org/wsdocs/ getdocument.aspx?docnum=626930. Acesso em: 15.set.2011. 
GOMES, M. C. 2003. Entrevista com Dr. Márcio Cidade Gomes (Coordenador da Coordenadoria de Contratação de Serviços de Saúde), realizada em maio de 2002. In: Relatório de Pesquisa n. 11. São Paulo: Fundação Getúlio Vargas. Disponível em: http://bibliotecadigital.fgv.br/ dspace/bitstream/handle/10438/2910/ P00253_1.pdf? sequence $=1$. Acesso em: 15.set.2011.

GUEDES, J. S. 2003. Entrevista com Dr. José da Silva Guedes (Secretário de estado da Saúde), realizada em novembro de 2002. In: Relatório de Pesquisa n. 11. São Paulo: Fundação Getúlio Vargas. Disponível em: http://biblio tecadigital.fgv.br/dspace/bitstream/handle/ 10438/2910/P00253_1.pdf?sequence=1. Acesso em: 15.set.2011.

IMMERGUT, E. 1996. As regras do jogo: a lógica da política de saúde na França, na Suíça e na Suécia. Revista Brasileira de Ciências Sociais, n. 30, p. 139-165, fev. Disponível em: http://www.anpocs.org.br/portal/publicacoes/ rbcs_00_30/rbcs30_13.htm. Acesso em: 15.set. 2011 .

KAUFMAN, R. 1998. A política da reforma do Estado: um exame de abordagens teóricas. Revista do Serviço Público, ano 49, n. 1, p. 4369, jan.-mar. Disponível em: http:// www.enap.gov.br/index.php?option $=$ com docman\&task=doc_download\&gid $=2889$. Acesso em: 15.set.2011.

KINZO, M. D. G. 1993. The 1989 Presidential Election: Electoral Behaviour in a Brazilian City. Journal of Latin American Studies, Cambridge (UK), v. 25, n. 2. p. 313-330, May.

2004. Partidos, eleições e democracia no Brasil pós-1985. Revista Brasileira de Ciências Sociais, São Paulo, v. 19, n. 54, p. 23-40. Disponivel em: http://www.scielo.br/pdf/ rbcsoc/v19n54/a02v1954.pdf. Acesso em: 15.set.2011.

LAMOUNIER, B. 1989. Partidos e utopias. O Brasil no limiar dos anos 90. São Paulo: Loyola.

1992. Estrutura institucional e governabilidade na década de 1990. In: VELLOSO, J. P. (org.). O Brasil e as reformas políticas. Rio de Janeiro: J. Olympio.
LIMA JR., O. B. 1983. Democracia e instituições políticas no Brasil dos anos 80. São Paulo: Loyola.

LIMONGI, F. 1994. O novo institucionalismo e os estudos legislativos: a literatura norte-americana recente. $B I B$, Rio de Janeiro, n. 37, p. 3-38.

LIPSKY, M. 1980. Street-Level Bureaucracy: Dilemmas of the Individual in Public Services. New York: Russel Sage Foundation.

MAINWARING, S. 2001. Sistemas partidários em novas democracias: o caso do Brasil. Rio de Janeiro: Fundação Getúlio Vargas.

MAINWARING, S. \& SAMUELS, D. 1997. Robust Federalism and Democracy in Contemporary Brazil. Paper presented at the XVI World Congress of Political Science, occurred at Seoul, South Korea, in August.

MAINWARING, S. \& SHUGART, M. (eds.). 1997. Presidentialism and Democracy in Latin America. Cambridge (UK): Cambridge University.

MAYHEW, D. 1974. The Electoral Connection. New Haven: Yale University.

MELO, M. 2002. Reformas constitucionais no Brasil: instituições políticas e processo decisório. Rio de Janeiro: Revan.

MENDES, M. (org). 2006. Gasto público eficiente: 91 propostas para o desenvolvimento do Brasil. Rio de Janeiro: Topbooks.

MODESTO, P. E. G. 1997. Reforma administrativa e marco legal das organizações sociais no Brasil. As dúvidas dos juristas sobre o modelo das organizações sociais. Revista do Serviço Público, Rio de Janeiro, v. 48, n. 2, p. 27-57, maio-ago. Disponivel em: http://www.bresser pereira.org.br/Documents/MARE/TerceirosPapers/97-Modesto,Paulo48(2).pdf. Acesso em: 15.set.2011.

NASCIMENTO, E. C. V. 2006. Entrevista com Eliana Cassiano Verdade Nascimento (Diretora Técnica de Departamento Secretaria de Estado de Saúde de São Paulo, Coordenadoria de Serviços de Saúde, Grupo de Gestão e Controle de Contratos). Entrevista realizada por Vera Viviane Schmidt, em junho. São Paulo: digit. 
NICOLAU, J. 2000. Disciplina partidária e base parlamentar na Câmara dos Deputados no primeiro governo Fernando Henrique Cardoso (1995-1998). Dados, Rio de Janeiro, v. 43, n. 4, p. 709-735. Disponível em: http:// www.scielo.br/scielo.php?script $=$ sci arttext\&pid=S0011-52582000000400004. Acesso em: 15.set.2011.

PSDB. 1988. Programa - introdução e diretrizes básicas. Disponível em: https://www2. psdb.org.br/wp-content/uploads/2010/04/ Programa_250688.pdf. Acesso em: 15.set.2011.

2006. A reforma do aparelho do Estado e as mudanças constitucionais - uma síntese. São Paulo: Partido da Social Democracia Brasileira. Disponível em: http://www.psdb.org.br. Acesso em: 11.nov.2006.

ROMA, C. 2002. A institucionalização do PSDB: entre 1988 e 1999. Revista Brasileira de Ciências Sociais, São Paulo, v. 17, n. 49, p. 7192, jun. Disponivel em: http://www.scielo.br/ $\mathrm{pdf} / \mathrm{rbcsoc} / \mathrm{v} 17 \mathrm{n} 49 / \mathrm{a} 06 \mathrm{v} 1749$.pdf. Acesso em: 15.set.2011.

SANTOS, F. 2003. O poder legislativo no presidencialismo de coalizão. Belo Horizonte: UFMG.

SANTOS, L.A. 1998. O programa de publicização e as Organizações Sociais. Disponível em: http://www.anesp.org.br/userfiles/file/estudos/ programa_publicizacao.pdf. Acesso em: 15.set.2011.
SARTORI, G. 1993. Nem presidencialismo, nem parlamentarismo. Novos Estudos Cebrap, São Paulo, n. 35, mar.

1994. A teoria da democracia revisitada: o debate contemporâneo. 2 V. São Paulo: Ática.

SCHMIDT, V. V. 2007. Coerência programática e disciplina parlamentar: partidos políticos frente à proposta das organizações sociais. São Paulo. Dissertação (Mestrado em Ciência Política). Universidade de São Paulo. Disponível em: http://www.teses.usp.br/teses/disponiveis/ 8/8131/tde-18122007-112529/pt-br.php. Acesso em: 15.set.2011.

SHUGART, M. \& CAREY, J. M. 1992. Presidents and Assemblies. Cambridge (UK): Cambridge University.

STEPAN, A. 1999. Para uma nova análise comparativa do federalismo e da democracia: federações que restringem ou ampliam o poder do demos. Dados, Rio de Janeiro, v. 42, n. 2. p. 197-251. Disponível em: http://www. scielo.br/scielo.php? script=sci arttext\&pid=S0011-52581999000200001. Acesso em: 15.set.2011.

YOSHIDA, I. F. 2006. Governadores estaduais e partidos políticos na reforma administrativa do governo FHC: negociação e análise da votação. São Paulo. Dissertação (Mestrado em Ciência Política). Universidade de São Paulo. Disponível em: http://www.teses.usp.br/teses/ disponiveis/8/8131/tde-22062007-142331/ptbr.php. Acesso em: 15.set.2011.

\section{OUTRAS FONTES}

BAHIA. s/d. Disponível em: http:// www.ba.gov.br. Acesso em: 15.set.2011.

BRASIL. 1988. Constituição Federal, de 3 de outubro. Constituição da República Federativa do Brasil - 1988. Diário Oficial da União, Brasília, 5.out.1988, p. 1, Anexo. Disponível em: http://www.planalto.gov.br/ccivil_03/ constituicao/constitui\%C3\%A7ao.htm. Acesso em: 15.set.2011.

1997. Medida Provisória n. 1.591, de 9 de outubro. Dispõe sobre a qualificação de entidades como organizações sociais, a criação do Programa Nacional de Publicização, a extinção do Laboratório Nacional de Luz Síncrotron e da Fundação Roquette Pinto e a absorção de atividades por organizações sociais, e dá outras providências. Diário Oficial da União, Brasília, 10.out.1997, Seção 1, p. 22835. Disponível em: http://www2.camara.gov.br/legin/ fed/medpro/1997/medidaprovisoria-1591-9. outubro-1997-376705-publicacaooriginal-1pe.html . Acesso em: 15.set.2011.

1998a. Emenda Constitucional n. 19, de 4 de junho. Modifica o regime e dispõe sobre princípios e normas da administração pública, servidores e agentes políticos, controle de despesas e finanças públicas e custeio de ativida- 
de a cargo do Distrito Federal, e dá outras providências. Diário Oficial Eletrônico, Brasília, 5.jun.1998, p. 1. Disponível em: http:// www.planalto.gov.br/ccivil_03/constituicao/ emendas/emc/emc19.htm. Acesso em: 15.set.2011.

1998b. Lei n. 9 637, de 15 de maio. Dispõe sobre a qualificação de entidades como organizações sociais, a criação do programa nacional de publicização, a extinção do Laboratório Nacional de Luz Síncrotron e da Fundação Roquette Pinto e a absorção de suas atividades por organizações sociais, e dá outras providências. Diário Oficial, Brasília, 18.maio.1998, p. 8. Disponível em: http:// www.planalto.gov.br/ccivil_03/leis/ L9637.htm. Acesso em: 15.set.2011.

BRASIL. Câmara dos Deputados. 1989. Resolução n. 17, de 1989. Aprova o Regimento Interno da Câmara dos Deputados. Brasília: Câmara dos Deputados. Disponível em: http:// www2.camara.gov.br/atividade-legislativa/ legislacao/Constituicoes_Brasileiras/regimentointerno-da-camara-dos-deputados/RICD $\% 20$ Resolucao\%2010-2009.pdf. Acesso em: 15.set.2011.

BRASIL. Ministério da Administração Federal e Reforma do Estado. 1997. Organizações sociais. Cadernos MARE n. 2. Brasília: Ministério da Administração Federal e Reforma do Estado. Disponível em: http://www.planejamento. gov.br/secretarias/upload/Arquivos/publicacao/ seges/PUB_Seges_Mare_caderno02.PDF. Acesso em: 15. set.2011.

BRASIL. Ministério da Saúde. Conselho Nacional de Saúde. 1997. Resolução n. 223 de 7 de maio. Diário Oficial da União, Brasília, 23.set.1997, Seção 1, p. 2-115. Disponível em: http://www.datasus.gov.br/conselho/resol97/ res22397.htm. Acesso em: 15.set.2011.

2011. Apresentação. Disponível em: http:/ /conselho.saude.gov.br/apresentacao/ apresentacao.htm. Acesso em: 15.set.2011.

BRASIL. Presidência da República. 1995. Plano diretor da reforma do aparelho do Estado. Brasília: Presidência da República. Disponível em: http://www.planalto.gov.br/publi_04/ colecao/plandi.htm. Acesso em: 15.set.2011.
BRASIL. Supremo Tribunal Federal. 2004. Banco nacional de dados do poder Judiciário. Ações Diretas de Inconstitucionalidade: 19882006. Disponível em: http://www.stf.gov.br/ bndpj/stf/ADIN. Acesso em: 2.jul.2010.

CEARÁ. s/d. Disponível em: http://www.ce. gov.br. Acesso em: 15.set.2011.

DATAINDICE. s/d. Banco de dados. Rio de Janeiro: Instituto Universitário de Pesquisas do Rio de Janeiro.

DISTRITO FEDERAL. s/d. Disponível em: http:/ /www.df.gov.br. Acesso em: 15.set.2011.

ESPÍRITO SANTO. s/d. Disponível em: http:// www.es.gov.br. Acesso em: 15.set.2011.

GOIÁS. s/d. Disponível em: http://www.go. gov.br. Acesso em: 15.set.2011.

Jornal do Senado. 1998a. Brasília, 12.maio. Disponível em: http://www.senado.gov.br/noticias/jornal/arquivos_jornal/arquivosPdf/ 19980512.pdf. Acesso em: 15.set.2011.

1998b. Brasília, 13.maio. Disponível em: http://www.senado.gov.br/noticias/jornal/ arquivos_jornal/arquivosPdf/19980513.pdf. Acesso em: 15.set.2011.

MARANHÃO. s/d. Disponível em: http:// www.ma.gov.br. Acesso em: 15.set.2011.

PARÁ. s/d. Disponível em: http://www.pa.gov.br. Acesso em: 15.set.2011.

PERNAMBUCO. s/d. Disponível em: http:// www.pe.gov.br. Acesso em: 15.set.2011.

SÃO PAULO. s/d. Disponível em: http:// www.sp.gov.br. Acesso em: 15.set.2011.

1989. Constituição estadual, de 5 de outubro. São Paulo: São Paulo. Disponível em: http://www.legislacao.sp.gov.br/legislacao/ index.htm. Acesso em: 15.set.2011.

1998a. Lei Complementar n. 846, de 4 de junho. Dispõe sobre a qualificação de entidades como organizações sociais e dá outras providências. Lex, São Paulo, v. 62, p. 906-913.

1998b. Projeto de Lei Complementar n. 3 de 1998. Diário Oficial do Estado, São Paulo, Seção I, p. 4-5, de 19.fev. 
SÃO PAULO. Assembléia Legislativa do Estado de São Paulo. 1998a. Audiência pública sobre organizações sociais, realizada em 15.abr. São Paulo: Assembléia Legislativa do Estado de São Paulo.

1998b. Processo de tramitação do Projeto de Lei Complementar n. 3 de 1998. São Paulo: Assembléia Legislativa do Estado de São Paulo.
SÃO PAULO. Conselho Estadual de Saúde. 1998. Minuta de Relatório da Comissão Técnica de Políticas de Saúde. Anexo a Ata de reunião de 22 de Julho de 1998.

SÃo PAULO. Procuradoria Geral do Estado. 1999. Parecer PA-3 n. 289, de 9.dez. São Paulo: Procuradoria Geral do Estado.

SERGIPE. s/d. Disponível em: http:// www.se.gov.br. Acesso em: 15.set.2011. 
PROGRAMATIC COHERENCE AND PARLIAMENTARY DISCIPLINE: POLITICAL PARTIES IN THE LIGHT OF THE SOCIAL ORGANIZATIONS PROPOSAL

Vera Viviane Schmidt

This article looks at the effect of political parties on the decision-making process of a policy for State reform called Social Organizations ("Organizações Sociais"). We analyze how it was proposed at federal and state (at the state of São Paulo) levels, and its adoption by other Brazilian states, during the period spanning 1995-2006. With regard to states' adoption of this policy - a discussion carried out here, considering the situation of state administrations, the governing political party and adoption or non-adoption of this policy - we take the Governor's party affiliation as a proxy for decisions to adhere or not to the model, through arguments that are economic or fiscal in nature. Legislative analysis demonstrates political party relevance in the structuring of the decision-making process and in guiding disciplined voting on the part of parliament members. The position of each party has, for the case in point, proved coherent with their respective programs.

KEYWORDS: Social organizations; political parties; public policy. 


\section{LA COHÉRENCE PROGRAMMATIQUE ET LA DISCIPLINE PARLEMENTAIRE : DES PARTIS POLITIQUES FACE À LA PROPOSITION DES ORGANISATIONS SOCIALES}

\section{Vera Viviane Schmidt}

Cet article traite de l'effet des partis politiques dans le processus de décision d'une politique de réforme de l'Etat, nommée « les Organisations Sociales» (OS). Sa proposition et sa procédure législative aux niveaux fédéral et régional (à l'état de São Paulo), et son adoption par les régions brésiliennes dans la période comprise entre 1995 et 2006 sont analysées. Par rapport à l'adoption de la politique par les régions, l'étude réalisée dans cet article - en considérant la situation des administrations régionales, le parti politique dans le gouvernement et l'adoption de cette politique ou non - on suggère que l'affiliation du Gouverneur au parti soit faite autant que proxy de sa décision d'adhérer ou non au modèle vis-à-vis des arguments de nature économique-fiscale. L'analyse législative a montré une importance des partis dans la structure du processus de décision et dans l'orientation du vote discipliné des parlementaires. La position de chaque parti a été, pour le cas observé, cohérente avec leurs programmes respectifs.

MOTS-CLÉS: Les Organisations Sociales ; les partis politiques ; les politiques publiques. 